Boylu, E. ve Işık, Ö. F. (2017). Türkçeyi yabancı dil olarak öğrenenlerin Türkçeye yönelik algılarının metaforlar aracılığı ile belirlenmesi. Ana Dili Eğitimi Dergisi, 5(3), 450-471.

$\begin{gathered}\text { Ana Dili Eğitimi Dergisi } \\ \text { Journal of Mother Tongue Education } \\ \text { www.anadiliegitimi.com }\end{gathered}$
Gelis/Received: 21.04 .2017 Kabul/Accepted:15.06.2017

\title{
Türkçeyi Yabancı Dil Olarak Öğrenenlerin Türkçeye Yönelik Algılarının Metaforlar Aracılığı ile Belirlenmesi
}

\author{
Emrah BOYLU* \\ Ömer Faruk IŞIK**
}

Öz

Bu çalışmada, Türkçeyi yabancı dil olarak öğrenenlerin Türkçeye yönelik algılarının belirlenmesi amaçlanmıştır. Çalışmaya 51'i erkek 49'u bayan olmak üzere A2,B1 ve B2 seviyelerinde Türkçe öğrenen toplam 100 öğrenci katılmıştır. Çalışmada katılımcıların Türkçeye ilişkin sahip oldukları metaforları ortaya çıkarmak amacıyla onların her birinden "Türkçe .......... gibidir, çünkü

cümlesini tamamlaması istenmiştir. Bu çalışmada nitel araştırma yöntemlerinden biri olan olgu bilim yaklaşımından yararlanılmıştır. Araştırmanın bulgularına göre, katılımcılar Türkçeye ilişkin olarak toplam 100 adet geçerli metafor üretmiştir. Bu bağlamda 100 metafor dikkate alınarak her metaforun kavramsallaştığı alana göre gruplara ayrılmış ve belli bir tema altında toplanmıştır. Bu metaforlardan 9 tanesi herhangi bir temaya yerleştirilemediği için değerlendirilmeye alınmamıştır. İşlemler sonunda toplam 4 farklı tema (Diller Arası Benzerlik, Olumlu His, ìntiyaç ve Kolay Bulma) oluşturulmuştur. Çalışma sonucunda, öğrencilerin 31'inin Türkçeyi intiyaç olarak gördüğü, 21'inin Türkçeyi zor bulduğunu, 9'unun Türkçeyi ana dili ile veya bildiği bir dille ilişkilendirdiği, 30’unun ise Türkçeye karşı olumlu bir his beslediği görülmektedir.

Anahtar Kelimeler: Yabancılara Türkçe Öğretimi, Metafor, Algı

\section{Determining the Perception of Students Who Learn Turkish as a Foreign Language toward Turkish by Means of Metaphors}

\begin{abstract}
In this study the aim was to determine the perceptions learners who learned Turkish as a foreign language toward Turkish. 100 students, 51 male and 49 female from A2, B1, and B2 levels took part in this research. Each participant was asked to complete the sentence stem "Turkish is like..., because..." to find out the metaphors they used for Turkish. In this study, phenomenological approach which is one of the qualitative research methods was used. According to the findings of the research, participants used 100 valid metaphors. Each metaphor was placed into a group based on the field it was conceptualized in and they were grouped under certain themes. 9 metaphors were discarded as it was not possible to place them into any theme. At the end of the analysis, a total of four different themes were formed (Similarity between Languages, Positive Feeling, Necessity, and Ease of Use). The findings showed that 31 students regarded Turkish as a necessity, 21 found Turkish difficult, 9 made connections between Turkish and their mother tongue or a language which they know well, and 30 had positive feeling toward Turkish.
\end{abstract}

Keywords: Teaching Turkish to foreigners, metaphor, perception

\footnotetext{
* Öğr. Gör. İstanbul Aydın Üniversitesi, Türkçe Öğretmenliği Bölümü, emrahboylu@aydin.edu.tr

** Okt. İstanbul Aydın Üniversitesi, Aydın TÖMER, ofarukisik@aydin.edu.tr
} 


\section{Giriş}

Dil öğretimi ve öğreniminin zor bir süreç olduğu inkâr edilemez bir gerçektir. Bu süreci etkileyen birçok etken bulunmaktadır. Bu etkenlerden bazıları şunlardır: Öğrencilerin kişisel ve bilişsel özellikleri, öğretmen, çevre, öğrenilen dilin zorluk-kolaylık durumu, öğrenilen dile karşı tutum, dile karşı algı, hedef dilin öğrenilme yeri vb. Bu bağlamda yabancı bir dil öğrenen bireylerin öğrendikleri dile karşı algıları, dil öğrenme başarılarını olumlu veya olumsuz yönde doğrudan etkileyecektir. Bu nedenle dil öğretiminde algı konusu üzerinde önemle durulması gereken bir konudur. Algı ise TDK (2017)'da "Bir şeye dikkati yönelterek o şeyin bilincine varma, idrak" olarak açıklanmıştır. Dil öğrenenlerin öğrendikleri dile karşı algılarını ölçmek için birden fazla yöntem mevcuttur. Bunlardan biri de algının "metaforlar" aracılığı ile belirlenmesidir.

Dilde ve edebiyatta en sık karşılaştığımız kelimelerden biri "metafor" kavramıdır. Metafor kelimesi etimolojik olarak Yunanca meta- "öte" ve pherein "taşımak, götürmek" ikilisinin birleşmesinden oluşmakta olup "nakletmek, öteye taşımak" anlamındadır (Demirci, 2016). Metafor kavramı, eğitim ve öğretim alanında özellikle 2000'li yıllarda sık sık kullanılmaya başlanmıştır. Öyle ki (Vadeboncoeur ve Torres (aktaran, Arslan ve Bayrakçı 2006: 101), metaforların eğitimdeki önemini şöyle açıklar: "Metaforlar çeşitli alanlarda kullanılabilmektedirler. Eğitim yönetiminden müfredat geliştirme ve plânlamada; öğretim alanında da öğrenmeyi teşvik etme ve yaratıcı düşünceyi geliştirmede başvurulmaktadır. Öğretmen eğitiminde ise metaforlar, öğretim uygulamalarını yönlendirmede ve öğretmenlerin modern eğitim anlayışlarındaki yerlerini belirlemede bir araç konumundadır." Buna ek olarak Şeyihoğlu ve Gençer (2011:84) de metaforların günlük yaşamdaki kullanımının dışında, eskiden beri eğitim ve öğretim amaçlı da karşımıza çıktığını ve öğretmenlerin, metaforları bilinçli veya bilinçsiz olarak genellikle fikirleri, kavramları ve soyut şeyleri açıklamak için kullandıkları vurgulamaktadır. Aydın ve Pehlivan (2010) da eğitimde metaforlardan planlama, eğitim programı geliştirme, öğrenmeyi teşvik etme ve yaratıcı düşünceyi geliştirmede yararlanılabileceğini belirtir. Bu çerçevede metaforların dil öğretiminde de kullanımı dil öğretiminde başarıya ulaşmada katkı sağlayacaktır.

Yabancılara Türkçe öğretimi literatürüne bakıldığında Türkçenin öğretiminde metafor kullanımı veya metafordan yararlanmanın çok az olduğu görülmektedir. Bu çerçevede ilgili alanyazında iki çalışmaya rastlanmıştır. Bu çalışmalardan biri Akkaya (2013)'nın "Suriyeli Mültecilerin Türkçe Algıları” isimli çalışmasıdır. Akkaya, bu çalışmasında 52 Suriyeli mültecinin Türkçeyle ilgili 36 metafor geliştirdiğini tespit etmiştir. Elde edilen verilerden hareketle, Suriyeli mültecilerin imaj dünyasının çok dar olmadığı, bununla birlikte, geliştirilen metaforların büyük bir çoğunluğunun (\% 96 ,2) olumlu, \% 3,8'inin ise olumsuz çağrışımlar oluşturduğu sonucuna varılmıştır. Bu verilerin, Suriyeli mültecilerin Türkçeye ilişkin olumlu bir tutum içerisinde olduklarını belirten araştırmacı 
Türkçeyi Yabancı Dil Olarak Öğrenenlerin Türkçeye Yönelik Algılarının Metaforlar Aracılığı İle Belirlenmesi

makalesinde Suriyeli mültecilerin en fazla anne, ev, insan metaforlarını kullandığını tespit etmiştir. Illgili çalışmalardan ikincisi ise Çalışkan (2010)'ın “Türkçenin Yabancı Dil Olarak Öğretiminde Söz Varlığını Geliştirme: Kavramsal Anahtarlar Aracılığıyla Deyim Öğretimi” isimli çalışmasıdır. Bu çalışmada araştırmacı, Türkçenin gerek yabancı dil gerekse ana dili olarak öğretimine yönelik metaforlardan yararlanma üzerine yapılan araştırma ve uygulamaların sınırlı olduğunu belirterek çalışmasında Kavramsal Metafor Teorisi'ni tanıtmış ve bu teori doğrultusunda oluşturulacak bir eğitim modeline ilişkin önerilerde bulunmuştur. Bu doğrultuda araştırmada günlük hayatta sık kullanılan, dolayısıyla Türkçeyi yabancı dil olarak öğrenenler için de önem taşıyan organ adlarıyla ilgili deyimlerin öğretimine yönelik bir çerçeve oluşturularak etkinlik örnekleri sunulmuştur. İki dilli çocuklara Türkçe öğretimi literatüründe ise Çalışkan (2013)'ın Kavramsal Anahtar Modeli ille Metafor ve Deyim Öğretimi” isimli çalışması ve yine Çalışkan (2009)'ın “Kavramsal Anahtar Modeliyle íki Dilli Çocuklara Metafor ve Deyim Öğretimi" isimli doktora tezi dil öğretiminde metaforu kapsamlı olarak ele almıştır. Türkçe öğretimde ise Dumanlı Kadızade (2014) “Aktif Öğrenmede Bir Teknik; Metafor Uygulaması "Türkçe Öğretmen Adaylarının Türkçe Dersi Algıları Üzerine" isimli çalışmasında Türkçe öğretmen adaylarının Türkçe derslerine yönelik algılarını belirlemeye çalışmıştır. Lüle Mert (2013) ise “Türkçe Öğretmen Adaylarının Dört Temel Dil Becerisine İlişkin Algılarının Metaforlar Aracılığıyla Analizi" isimli çalışmasında metaforu öğretmen adaylarının dört temel dil becerisine yönelik algılarını ölçmede kullanmıştır. Pilav ve Elkatmış, (2013) ise "Öğretmen Adaylarının Türkçe Kavramına İlişkin Metaforları” isimli çalışmalarında Türkçe öğretmeni ve sınıf öğretmeni adaylarının Türkçe algıları tespit etmişlerdir. Göçer (2013) de "Türkçe Öğretmeni Adaylarının 'Kültür Dil illişkisi'ne Yönelik Metaforik Algıları." isimli çalışmasında Türkçe öğretmeni adaylarının kültür dil ilişkisine yönelik algılarını metaforlar yoluyla ortaya çıkarma amacıyla gerçekleştirilmiştir.

Bu çalışmalar ışığında Türkçe öğretiminde metafor kullanımı ve öğretimi üzerine akademik çalışmaların sayısının ve araştırma konularının çeşitliliğinin artırılması elzem olarak görülmektedir. Öyle ki Çalışkan (2010) da ilgili çalışmasında özellikle ikinci dil öğretimi alanında ve daha çok üniversite öğrencilerine yönelik olarak yapılan metafor farkındalığı geliştirme çalışmalarından verimli sonuçlar elde edildiğini fakat bu alanda Türkçenin gerek yabancı dil gerekse ana dili olarak öğretimine yönelik araştırma ve uygulamaların sınırlı olduğunu belirtmiştir. Bu doğrultuda, Çalışkan (2010) çalışmasında, günlük hayatta sık kullanılan, dolayısıyla Türkçeyi yabancı dil olarak öğrenenler için de önem taşıyan organ adlarıyla ilgili deyimlerin öğretimine yönelik bir çerçeve oluşturularak etkinlik örnekleri sunmuştur. Türkçeyi yabancı dil olarak öğrenenlerin ve öğretenlerin en çok zorlandığı konulardan biri olan deyim öğretiminde metaforlardan yararlanmanın başarıya ulaşmada doğrudan katkısı olduğu düşünüldüğünde yabancılara Türkçe öğretimi ile ilgili akademik çalışmaların azlığı üzücü bir durumdur. Bu nedenle bu çalışma ile metaforların yabancı dil olarak Türkçeyi öğrenen 
öğrencilerin Türkçeye karşı algılarının ölçülmesinde kullanılabilecek en iyi yöntemlerden biri olduğu ortaya koymak da amaçlanmaktadır.

Bu araştırmanın amacı, Türkiye'de Türkçeyi yabancı dil olarak öğrenen öğrencilerin Türkçeye ilişkin algılarını metaforlar aracılığıyla belirlemektir. Bu genel amacı gerçekleştirmek için aşağıdaki sorulara cevap aranmıştır.

1. Öğrenciler Türkçeye ilişkin algılarını hangi metaforlarla açıklamaktadırlar?

2. Öğrencilerin Türkçeye ilişkin ürettikleri metaforlar hangi temalar altında toplanmaktadır?

2.1. Kur seviyelerine göre öğrencilerin ürettikleri metaforların temalara göre dağıımı nasıldır?

2.2. Cinsiyetlere göre öğrencilerin ürettikleri metaforların temalara göre dağııımı nasıldır?

2.3. Ülkelere göre öğrencilerin ürettikleri metaforların temalara göre dağılımı nasıldır?

2.4. Aynı dil ve yakın kültüre sahip Arap uyruklu öğrencilerin ürettikleri metaforların temalara göre dağııımı nasıldır?

\section{Yöntem}

$\mathrm{Bu}$ araştırmada nitel araştırma yöntemlerinden biri olan olgu bilim (fenomenoloji) yaklaşımından yararlanılmıştır. Yıldııı ve Simsek, (2011) olgu bilim araştırmalarını, farkında olunan ancak derinlemesine ayrıntılı bir anlayışa sahip olunmayan olgulara odaklanılması olarak tanımlamaktadır. Bu bağlamdan hareketle ilgili araştırmada, Türkçeyi yabancı dil olarak öğrenenlerin Türkçe hakkındaki algıları metafor yardımı ile belirlenmeye çalışılmıştır.

\section{Çalışma Grubu}

Araştırmanın çalışma grubunu İstanbul Aydın Üniversitesi Aydın TÖMER'de A2, B1, B2 seviyesinde Türkçe öğrenen farklı ülkelerden 100 öğrenci oluşturmaktadır. Çalışma gurubuna ait demografik bilgiler aşağıdaki gibidir:

Tablo 1: Araştırma katılımcılarına ait demografik bilgiler

\begin{tabular}{cccc}
\hline Özellikler & & (f) & (\%) \\
\hline \multirow{3}{*}{ Yaş } & $15-20$ & 26 & 26 \\
& $20-25$ & 40 & 40 \\
& $25-30$ & 17 & 17 \\
& $30-35$ & 13 & 13 \\
& $35+$ & 4 & 4 \\
Cinsiyet & & & 51 \\
& Erkek & 51 & 49 \\
\hline
\end{tabular}




\begin{tabular}{|c|c|c|c|}
\hline & $\mathrm{A} 2$ & 42 & 42 \\
\hline \multirow[t]{10}{*}{ Seviye } & B1 & 41 & 41 \\
\hline & B2 & 17 & 17 \\
\hline & Afganistan & 26 & 26 \\
\hline & Çin & 7 & 7 \\
\hline & Fas & 2 & 2 \\
\hline & Filistin & 8 & 8 \\
\hline & G. Kore & 2 & 2 \\
\hline & Irak & 5 & 5 \\
\hline & İran & 8 & 8 \\
\hline & Misır & 6 & 6 \\
\hline \multirow{9}{*}{ Ülke } & Pakistan & 1 & 1 \\
\hline & Rusya & 1 & 1 \\
\hline & Somali & 2 & 2 \\
\hline & Suriye & 19 & 19 \\
\hline & Suudi Arabistan & 1 & 1 \\
\hline & Tunus & 4 & 4 \\
\hline & Ukrayna & 3 & 3 \\
\hline & Ürdün & 2 & 2 \\
\hline & Yemen & 3 & 3 \\
\hline Toplam & - & 100 & 100 \\
\hline
\end{tabular}

Tablo 1'e bakıldığında araştırmaya katılanların 51'inin erkek 49 'unun ise bayan olduğu, 42'sinin A2 41'inin B1 ve 17'sinin B2 seviyesinde Türkçe öğrendiği ve 26'sının 15-20, 40'ının 20-25, 17'sinin 25-30, 13'ünün 30-35, 4'ünün 35+ yaşında olduğu görülmektedir. Bunlara ek olarak öğrencilerin yoğun olarak Afganistanlı (26) Suriyeli (19) ve Filistinli (8) Çinli (8) Iraklı (5) İranlı (8) ve Mısırlı (6) olduğu anlaşılmaktadır.

Yukarıdaki bilgiler çerçevesinde bayan ve erkek öğrencilerin sayısının birbirine çok yakın olması Türkçenin özellikle bayan öğrenciler tarafından da yoğun bir şekilde öğrenilmeye başlandığını, yüksek seviyelerde (B2-C1) öğrenci sayısının azaldığını ve yoğun olarak Orta Doğu'daki ülkelerden 
gelen öğrencilerin Türkçe öğrendiği söylenebilir. Ayrıca öğrencilerin yaş aralığı dikkate alındığında 100 öğrenciden 83'ünün 15-30 yaş aralığında olması Türkçenin daha yoğun olarak gençler tarafından öğrenildiğini söylenebilir.

\section{Verilerin Toplanması}

İlgili literatür incelendiğinde metaforlarla algının ölçülmeye çalışıldığı çalışmalarda verilerin toplanmasında "XXX. gibidir, çünkü " ifadesinin tamamlatıldığı görülmüştür (Fidan, 2014; Göçer, 2013; Akkaya, 2013; Saban, 2008; Kalyoncu, 2012) Bu çalışmanın verileri toplanırken de aynı yol izlenmiştir. Katılımcıların Türkçe kavramına ilişkin sahip oldukları algılara yönelik metaforları ortaya çıkarmak amacıyla onların her birinden "Türkçe gibidir, çünkü .." cümlesini tamamlaması istenmiştir. Öğrencilerin kişisel bilgilerini toplamak amacıyla da bir kişisel bilgi formu oluşturulmuştur. "Türkçe gibidir, çünkü ." ifadesine ilişkin öğrencilerin görüşleri yazılı olarak toplanmıştır. Öğrenciler, ilgili çalışma hakkında, formlar doldurulmadan önce araştırmacı tarafından bilgilendirilmiştir.

\section{Verilerin Analizi}

Alan yazın incelendiğinde Saban (2008), Altun ve Apaydın (2013) ve Akkaya (2013)'nın ilgili çalışmalarının öğrencilerin metaforlarının belirlenmesine yönelik olduğu görülmektedir. Bu bağlamda her üç çalışmada da öğrencilerin metaforların analiz edilmesi ve yorumlanması süreci dört aşamada gerçekleştirilmiştir: 1. Adlandırma aşaması 2. Eleme ve arıtma aşaması 3. Derleme ve kategori geliştirme aşaması 4. Geçerlik ve güvenirliği sağlama aşaması. Bu bağlamda bu araştırmada da verilerin analiz edilmesi ve yorumlanmasında analizler, bu üç çalışma esas alınarak yapıımıştır.

1. Adlandırma Aşaması: Bu süreçte öğrencilerden toplanan kâğıtlar öğrencilerin anlamlı metaforlar ve mantıklı açıklama yapıp yapmadıkları açısından kontrol edilmiştir.

2. Eleme ve Arıtma Aşaması: Bu aşamada metaforlar, konusu, kaynağı ve konusu ile kaynağı arasındaki ilişki olmak üzere 3 bakımdan ele alınmış ve tasnif edilmiştir. 100 öğrenciye yapılan uygulama çerçevesinde değerlendirilen 100 kâğıttan metafor ve kaynağı arasında bir anlam ilişkisi olmayan metafor olmadığı için çalışmada verilerin tamamı kullanılmıştır.

\section{Derleme ve Kategori Geliştirme Aşaması:}

Bu aşamada öğrencilerin Türkçeye yönelik olarak ürettikleri metaforlar, sahip oldukları ortak özellikler bakımından incelenmiştir. Bu bağlamda 100 metafor dikkate alınarak her metaforun kavramsallaştığı alana göre gruplara ayrılmış ve belli bir tema ismi altında toplanmıştır. Bu işlemler sonunda toplam 4 farklı tema (Diller Arası Benzerlik, Olumlu His, İhtiyaç ve Kolay Bulma) oluşturulmuştur. 
Türkçeyi Yabancı Dil Olarak Öğrenenlerin Türkçeye Yönelik Algılarının Metaforlar Aracılığı İle Belirlenmesi

\section{Geçerlik ve Güvenirlik Sağlama Aşaması:}

Araştırmanın güvenirliğini sağlamak için, araştırmada 4 tema altında toplanan metafor imgelerinin söz konusu temayı temsil edip etmediğini teyit etmek amacıyla uzman görüşüne başvurulmuştur. Bu amaç doğrultusunda, aynı birimde ders veren bir okutmana 100 adet örnek metafor imgesinin alfabetik sıraya göre dizili olduğu bir liste ve 4 tema ismi ile özelliklerini içeren iki liste verilmiştir. Okutmandan bu iki listeyi de kullanarak birinci listedeki örnek metafor imgelerini ikinci listedeki 4 tema altında (hiçbir metafor imgesini dışarıda bırakmayacak şekilde) toplaması istenmiştir. Daha sonra, ilgili kişinin yaptığı eşleştirmeler araştırmacının kendi kategorileriyle karşılaştırılmıştır. Karşılaştırmalarda "görüş birliği" ve "görüş ayrılı̆ı"” sayıları tespit edilerek araştırmanın güvenirliği Miles ve Huberman'ın (1994) formülü (Güvenirlik = görüş birliği / görüş birliği + görüş ayrılığı X 100) kullanılarak hesaplanmıştır (aktaran Saban, 2008: 467) Güvenirlik çalışması kapsamında görüşüne başvurulan uzman, 9 metaforu (Bahçe, İlkokul birinci sınıf, Suriye, Sebze Karıştır, Su, Su içmek, Trump Tover, Yüzme öğrenme, Zengin Bir İnsan) araştırmacılardan farklı bir kategoriyle ilişkilendirmiştir. Bu durumda güvenirlik $=91 / 91+9 \times 100=\% 91$ olarak hesaplanmıştır. Yazarlara göre, uzman ve araştırmacı değerlendirmeleri arasındaki uyumun \%90 ve üzeri olduğu durumlarda arzu edilen düzeyde bir güvenilirlik sağlanmış olmaktadır (Saban, 2008: 467).

\section{Bulgular ve Yorum}

Bu bölümde, Türkçeyi yabancı dil olarak öğrenenlerin, Türkçeye yönelik geliştirdikleri metaforlarla ilgili olarak elde edilen bulgular tablolar hâlinde analiz edilerek yorumlanmıştır.

Öğrenciler Türkçeye ilişkin algılarını hangi metaforlarla açıklamaktadırlar?

Türkçeyi yabancı dil olarak öğrenen öğrencilerin Türkçeye ilişkin geliştirdikleri metafor listesi aşağıdaki gibidir:

Tablo 2: Türkçe ile ilgili Metaforlar

\begin{tabular}{ll}
\hline Metafor & Tekrar Sayısı \\
\hline Ağaç & 1 \\
Ailem & 1 \\
Altın & 1 \\
Anahtar & 3 \\
Annem & 1 \\
Arapça & 1 \\
Araç & 1 \\
Arapça aksine (Ters) & 1 \\
Arkadaşım & 2 \\
Ay & 1 \\
Babam & 1 \\
Bahçe & 2 \\
Baklava & 2 \\
Balık tutmak & 1
\end{tabular}

\begin{tabular}{ll}
\hline Metafor & $\begin{array}{l}\text { Tekrar } \\
\text { Sayısı }\end{array}$ \\
\hline Klavuz & 1 \\
Korece + Ingilizce + biraz & 1 \\
Arapça & \\
Köşe taşı & 1 \\
Kütüphane & 1 \\
Labirent & 1 \\
Lazım iş & 1 \\
Makarana & 1 \\
Meyve ağaçları & 1 \\
Okul & 1 \\
Oyun & 1 \\
Oyuncak tramvay & 1 \\
Ödül & 1
\end{tabular}




\begin{tabular}{|c|c|c|}
\hline Balık tutmak & 1 & Ödül \\
\hline Başarılı bir yaşam & 1 & Panda \\
\hline Benim eski dilim & 1 & Papağan sesi \\
\hline Buzdolabı & 1 & Parfüm \\
\hline Çok zor & 1 & Puzzle mozaik \\
\hline Dağ & 1 & Resim \\
\hline Define & 1 & Restoran \\
\hline Deniz & 3 & Saat \\
\hline E5 & 1 & Salata \\
\hline illaç & 1 & Sapsarı altın \\
\hline Elmas & 1 & Sebze karıștır \\
\hline Farsça & 2 & $\begin{array}{l}\text { Sebze karıștır } \\
\text { Sorun cözmek }\end{array}$ \\
\hline Film & 1 & Sorun çözmek \\
\hline Google & 1 & Spor \\
\hline Güç ve kuvvet & 1 & Su \\
\hline Güçlü ve kibar & 1 & Su içmek \\
\hline Güneş & 1 & Suriye \\
\hline Güneșin Ișığı & 1 & Telefon \\
\hline Güzel bir dil & 1 & Tercüman \\
\hline Güzel bir insan & 1 & Ters koşan bir adam \\
\hline Hava & 1 & Toz (tuz) \\
\hline Hırsız & 1 & Tren \\
\hline $\begin{array}{l}\text { Ilık bir mekân } \\
\text { ilkokul 1. sınıf }\end{array}$ & $\begin{array}{l}1 \\
1\end{array}$ & Trump tover \\
\hline İş & 1 & Uçak \\
\hline Kadınlar & 1 & Uzun verimli bir ağaç \\
\hline Kanarya sesi & 1 & Uzun, geniş ve tatlı sulu bir \\
\hline Kar & 1 & $\begin{array}{l}\text { nehir } \\
\text { Yapboz }\end{array}$ \\
\hline Karışık meyve suyu & 1 & Yardımcı \\
\hline Kekeme & 2 & Yaşam \\
\hline \multirow[t]{3}{*}{ Kız, nazik ve kibar } & 1 & \\
\hline & & Yüzme Ögrenme \\
\hline & & Yüzmek \\
\hline \multicolumn{2}{|l|}{ Toplam 100} & Zengin bir insan \\
\hline
\end{tabular}

Yukarıdaki tabloya bakıldığında öğrencilerin genel olarak Türkçeye ilişkin geliştirdikleri metaforların birbirlerinden farklı olduğu görülmektedir. Bu çerçevede kekeme (2), tren (2), su (4), sorun çözmek (2), anahtar (3), Farsça (2), deniz (3), baklava (2), bahçe (2), arkadaş (2) metaforları birden fazla öğrenci tarafından üretilmiştir. Burada dikkat edilmesi gereken önemli hususlardan biri ise hemen hemen her öğrencinin Türkçeye ilişkin bir metafor üretebilmesidir. Özellikle Türkçeyi yabancı dil olarak öğrenenlerin ürettikleri metaforlara bakıldığında Türkçenin öğrencilerin düşünce dünyalarındaki yeri ortaya çıkmaktadır. Bu nedenle bu tür durumların tespiti de dil öğretiminde başarıyı doğrudan etkileyecektir. Örneğin Türkçeye yönelik geliştirdiği metafor baklava olan bir 
öğrenci ile labirent olan bir öğrencinin Türkçeye yönelik algılarının aynı olduğunu söylemek imkânsızdır.

\section{Öğrencilerin Türkçeye ilişkin ürettikleri metaforlar hangi temalar altında toplanmaktadır?}

Bu bölümde öğrencilerin Türkçeye ilişkin ürettikleri metaforların hangi temalara ayrıldığına ilişkin tablolar ve yorumlar bulunmaktadır.

Tablo 3: Öğrencilerin Türkçeye ilişkin ürettikleri metaforların temalara göre dağılımı ile ilgili veriler

\begin{tabular}{lllllll}
\hline & Olumlu His & intiyaç & Diller Arası İlişki & Zor bulma & Tasnif dışı & Toplam \\
\hline Toplam & 30 & 31 & 9 & 21 & 9 & 100
\end{tabular}

Tablo 3'e bakıldığında öğrencilerin Türkçeye ilişkin ürettikleri metaforların 30'u Olumlu His, 31'i îhtiyaç, 9'u Diller Arası Illişki ve 21'i ise Zor Bulma temasında olduğu görülmektedir. 9 öğrencilerin ürettiği metafor ise herhangi bir tema ile ilişkilendirilemediği için tema dışı bırakılmıştır.

Öğrencilerin ürettikleri metaforların temalara göre detaylı dağılımını gösteren tablolara ise aşă̆ıdaki gibidir:

Tablo 4: Türkçeyi ihtiyaç olarak görenlerin ürettikleri metaforlara ilişkin veriler

\begin{tabular}{|c|c|c|}
\hline No & Metafor & Metaforun Gerekçesi \\
\hline Ö1 & Araç & $\begin{array}{l}\text { İstiyacğim ve benim ailemi ve çocuklarım ile burada yaşıyoruz ve eğilim sistem ve } \\
\text { hastana ve her şey Türkçe konuşmak gerek. bu yüzden her adam turkçe dil } \\
\text { oğranıyor mecbur olabilir. Ayrıca iş için Türkçe takip lazım. }\end{array}$ \\
\hline Ö2 & Güneş & Güneş benim için çok önemli. Her zaman yeni hayat ve yeni gün bu demek. \\
\hline 0̈3 & Lazım iş & $\begin{array}{l}\text { Türkiye'de derslerime devam ediyorum ve iş için daha iyi konuşmak, yazmak ve } \\
\text { okumak lazım ki öğreniyorum. }\end{array}$ \\
\hline Ö4 & Su & $\begin{array}{l}\text { Ben Türkiye'de yaşıyorum bu yüzden Türkçe hayatımda çok önemli. Bir de Türk } \\
\text { okula gideceğim ve Türk arkadaşla tanışacağım. }\end{array}$ \\
\hline Ö5 & Yardımcı & $\begin{array}{l}\text { İstanbul'da yaşıyorum ve her zaman dışarıya çıkıyorum alışveriş için ya da bir şey } \\
\text { almak için veya bir yere gitmek istiyorum. O zaman Türkçe benim yardım ediyor.. }\end{array}$ \\
\hline Ö10 & Annem & $\begin{array}{l}\text { Her gün lazım, konuşuyorum, nefret ediyorum sonra çok seviyorum, daha } \\
\text { öğrenmekten sonra iyi olacağım. Bu yüzden Türkçe annem gibidir. }\end{array}$ \\
\hline Ö11 & Resim & $\begin{array}{l}\text { Herkes Türkçe bilmiyor ama ben şimdi istanbulda yaşıyorum ve Türkçesiz yaşamak } \\
\text { zor olabilir herkes resim anlamıyor ama resim öğrenmek güzel bir şey değil mi? }\end{array}$ \\
\hline Ö12 & Çok zor & $\begin{array}{l}\text { Ben burada tek yaşarım ve hiç arkadaş yok yani ben şimdi Türk kursuna gidirim } \\
\text { ama perktiş lazım zaten konuşmak istiyorum. }\end{array}$ \\
\hline Ö13 & Spor & Pratik lazım masal sporda her insan çaba yapiyor ve ben ayrıca çaba yapıyorum. \\
\hline Ö15 & Hava & $\begin{array}{l}\text { Bu çok önemli ben türkeyde yaşiyorum bu yüzden bu çok önemlidir. Türkçe } \\
\text { öğreniyorum çünkü bütün insanlar türkçe konişiyor ve türk insanlar başak dil }\end{array}$ \\
\hline
\end{tabular}


konuşmak hoşlanmıyor.

Ö16 Köşe taşı

0̈17 Anahtar

ö18 ilaç

Ö28 Anahtar

Ö35 Tercüman

0̈36 Sorun çözmek

Ö37 Başarılı bir yaşam

Ö43 Define

Ö44 Ağaç

Ö45 Kılavuz

Ö46 Altın

Ö48 Okul

Ö50 Sorunların çözümü

Ö51 Yaşam

Ö52 iş

Ö68 Babam

ö76 Deniz

Ö86 Sapsarı altın
Ben doktorum ve istanbul'da çalışmak istiyorum bu yüzden Türkçe çok önemlidir. Çünkü hayat kurmak için çok lazım.

Benim geleceğimin anahtarıdır. Burada yaşamak için öğrenmem lazim hemde çok seviyorum benim için anadilimden başka ikinci en güzel dil sayılır.

Çok tatlı değil ve Türkçe öğrenmek çok iyidir ama bazan da çok zordu ama türkçe öğrenmek çok önemlidir. Hasta gibi ki ilaç istiyor.

Türkiye'de yaşıyorum. Türkiye'deki insanlar ile konuşabilirim. İşebilirim. Bana Türk arkadaşlar almak için.

Türkiye'de yaşıyorum ondan sonra okula okumak istiyorum. Sonra ticaret yapıcağım mermer ticaret satış yapıcağım ama öncede Türkçe daha iyi her insanlara yardım ediyor tercüman gibi.

Herkes Türkçeyi öğreniyor rahat rahat İstanbula gezebilir. Eğir öğrenmezse o zaman evde oturmanız girekiyorsunuz. 5 ay önce hiçbir yeri sevmiyordum. Çünkü bu kadar Türkçe anlatmıyordum. Ve artık sakakta geze geze konuşuyorum ve herkesle sorularımı çözmeliyim ve çok çok rahatım.

Türkleri anlamak istiyorum, başka kültürleri biliyorum, başka bir yaşam yaşıyorum, çeşitli yemekleri tadıyorum. Ayrıca benim kültürümü insanlara anlatıyorum çünkü benim kültürüm çok çeşitli, heyecanlı ve Türk kültürüne yakın.

Her kişi öğrenmek için gereklidir. Bu dili ihtiyacı herkes.

Ben bu ağaçtan meyvesini yeyecem. İyi şeyleri kolnacam ve ülkemi ve Türkiye yardim edecem.

Türkçe yani Tomer bitiktan sonra ben aconomey fakkültesinde başlacağım. Bu yüzden bana klavuz gibidir.

O çok önemli. Ben yaşarım orda bu yüzden Türkçe altın gibidir.

O önemli Türkçe buna okul gibi bu için öğrenme gerekli ve tamamen orada bo için sorunlarını çözme islihdam yapcım bo için öğreniyorum.

Bin her yerde gitsem Türkçe bana yardım ediyor ve heç yerde sekanta olmayacak,

Dört gözle beklemek ben burada yapacağım. O zaman sadece Türkçe konuşmak istiyorum. Ayrıca ben Türk arkadaşlar buluşmak istirim. Bu yüzden Türkçe yaşam.

Ilk Turkey geldim hiç Türkçe dil konuşmak bilmiyordum sadece ingilizce biliyorum bu yüzden hayat istanbul da çok zor oldumak için Türkçe dil okuyorum burad iş yapacağım sonra evleneceğim bir güzel ve iyi kiz ile

Babam banu para veriyor ve Türkçe öğranıp para kazanacağım.

Türkçe bür büyük dil dir. Her insan bilirki örenceckı mesle bu kadar büyük dur ki gençler ve ya ekki adamlar bilirki örenecek. Büyük ve kücük değil örenmek için her yerde sıcak ve soğuk da o bilir örenmek

Altın her insan dünyadaki istiyor ve giymek istiyor, her yer yokmuş sadece bir yerde varmış, kimse türkçe öğrenmek istiyor mecbur türkiyeye gidiyor, altın gibi, kimse Altın istiyor, altın altın yerlere mecbur gidiyor. 


\begin{tabular}{lll}
\hline Ö89 Su & $\begin{array}{l}\text { Hayat susuz olmaz yaşanmaz su hayat demek su güzellik demek ve Türkçe hayat } \\
\text { demek }\end{array}$ \\
Ö72 Tren & $\begin{array}{l}\text { Tren güçlü, doğru yolda, hızlı yolan gitmemiş. Ayrıca onun hedef yetişebilir. Bana } \\
\text { Türkçe öğrenmem çok önemli bu yüzden, tren gibi ihtiyacım var. }\end{array}$ \\
Ö42 Anahtar & $\begin{array}{l}\text { Her şey istiyorsunuz türkçe konuşmayız lazım okulda hastana'da her yerde } \\
\text { kullanılırız. O zaman Türkçe dil biliyoruz her şey kolay olacak. En sonu Türkçe } \\
\text { biliyoruz hayatiniz Türkiye'ye daha mutlu. }\end{array}$
\end{tabular}

Tablo 4'e bakıldığında 31 öğrencinin Türkçeyi ihtiyaç olarak gördüğü ve bu bağlamda metafor ürettikleri dikkat çekmektedir. Özellikle bazı öğrencilerin ( Ö89, Ö51, Ö18, Ö15, Ö,10 Ö4, Ö2) Türkçeyi insanoğlunun yaşamını sürdürebilmesi için var olan temel ihtiyaçlarla ilişkilendirmesi Türkçeye yönelik algının ne derece kuvvetli olduğunu göstermesi bakımından son derece önemlidir. Bu açıdan bakıldığında Ö89 numaralı öğrenci Türkçeyi "su" metaforu ile açıklamış ve metaforun gerekçesini "Hayat susuz olmaz yaşanmaz su hayat demek su güzellik demek ve Türkçe hayat demek." olarak belirtmiştir. Ö4 numaralı öğrenci de Türkçeyi "güneş" metaforu ile açıklamış ve "Ben Türkiye'de yaşıyorum bu yüzden Türkçe hayatımda çok önemli. Bir de Türk okula gideceğim ve Türk arkadaşla tanışacağım." şeklinde metaforun gerekçesini açıklamıştır. Ö10 numaralı öğrenci ise "annem" metaforu ile Türkçeyi açıklamaya çalışmış ve gerekçesini şöyle belirtmiştir: "Her gün lazım, konuşuyorum, nefret ediyorum sonra çok seviyorum, daha öğrenmekten sonra iyi olacağım. Bu yüzden Türkçe annem gibidir." Verilerden hareketle öğrencilerin Türkçeyi ihtiyaç olarak gördükleri ve bu nedenle Türkçe öğrendikleri söylenebilir.

Tablo 5: Türkçeye karşı olumlu his besleyenlerin ürettikleri metaforlara ilişkin veriler

\begin{tabular}{|c|c|c|}
\hline No & Metafor & Metaforun Gerekçesi \\
\hline Ö8 & Ay & $\begin{array}{l}\text { Ay her vakit çıkamaz sadece gece çıkıyor. Bu yüzden geceni ışık eder. İşte böyle } \\
\text { Türkçe benim için bir ay gibidir. }\end{array}$ \\
\hline Ö9 & Parfüm & $\begin{array}{l}\text { Bu ilk yapancı dil öğreniyorum ve benim toplumumda hiç kimse Türkçe bilmiyor ve } \\
\text { onu seviyorum. }\end{array}$ \\
\hline Ö24 & Kız, nazik ve kibar & $\begin{array}{l}\text { Çok kibar cümleler var. Her şeyin ismi çok nazik çok nazik harfler var. Benim en } \\
\text { sevdiğim dil Türkçedir. }\end{array}$ \\
\hline Ö26 & Kanarya sesi & Türkçe gramer çok yumuşak ve rahat, Telafuz çok kolay. \\
\hline Ö27 & Papağan sesi & Türkler çok konuşur ve zaten papağan sesi tatlıdır. \\
\hline Ö29 & Oyun & O hem çok eğlence ve güzel bir dil hem de asla sıkılmayacaksın. \\
\hline Ö30 & Arkadaşım & Ben her zaman onunla beraberim. Kendimi hiç yalnız hissetmiyorum. \\
\hline Ö39 & Güç ve kuvvet & $\begin{array}{l}\text { Türkiye eski zamandan beri güçlü bir dil. Türkçe gelişmeye ve kuvvetlenmeye } \\
\text { devam ediyor. }\end{array}$ \\
\hline Ö41 & Restoran & $\begin{array}{l}\text { Türkiye'de restoran gibi çok farklı diller ve insanlar var. Türkiye'de insanlar yüksek } \\
\text { sesli ve özgür olarak konuşuyorlar. Bir müzik notaları gibi kaynaşan çeşitli }\end{array}$ \\
\hline
\end{tabular}


ülkelerden insanlar var. Bunun için Türkçeyi ve Türkiye'yi çok seviyorum.

Ö49 Bahçe

Ö54 Kütüphane

Ö55 Güneşin ışı̆̆ı

Ö60 Baklava

Ö61 Ailem

Ö63 Benim eski dilim

Ö64 Güzel bir dil

Ö66 Meyve ağaçları

Ö75 Uçak

Ö77 Hırsız

Ö79 Ilık bir makan

Ö80 Kadınlar

ö83 Baklava

Ö84 Güzel bir insan

Ö85 Panda

Ö93 Elmas

ö98 Salata

Ö99 Güçlü dili ve kibar

Ö71 Deniz

Ö56

Uzun, geniş ve tatlı sulu bir nehir
Türkçe bahçe gibidir. Biz onun meyvelerini yiyoruz. Türkçe bizim için çok önemli bir dildir.

Türkçe zengin bir dildir. Ne konu istersen kütüphanede vardır. Her şey Türkçede de vardır.

Güneş parlıyor ve her şeyi gösteriyor aynan Türkçe parlayınca her şeyi bu dünyadaki altında geliyor ve bu dünyadaki şeyler Türkçede ve bu dünyadaki şeyler Türkçede anlatma var.

Baklava çok güzel bir tatlı ve ben bunu çok seviyorum ve Türkçe tatlı ve güzel bir dil ve zaten çok zor hem değil ve biraz benim dilim gibi yani farsça gibidir.

Türkçe bana sıcak ve mutluluk hissedirir.

Benim ana dilim eski Türkçedir. Türkçe çok tatlı çok güçlü sanatsal bir dildir.

Her dil farklı bir dildir. Çünkü ben Türkçeyi çok seviyorum çünkü Türkçe çok kibar ve yumuşak bir dil.

Türkçe çok zengin bir dil ayni anlamda birden fazla kelime var, çok eğlenceli ve güzel bir dil.

Her zaman Türkçe herfleri hava da geziyor Türkçe dile çok seviyorum

Kalbini çalar ve çok güzel dil.

Dili çok kolay her yerleri güzel, hem temiz yardım sever yabancılara karşı.

Çok zor anlıyor. Ama aynı zaman çok güzel bir şey ve her zaman onun istiyoruz.

Ne zaman Türkçe öğretiyor ve anlıyor o zaman hissediyor daha çok Türkçe öğretmek istiyor. Baklava gibi ne zaman Baklava yiyor. Hessetiyor daha baklava istiyor.

İçinde her şey var ve tam bir dildir ve her insan çok kolay bu dil (Türkçe) öğreniyor ve konuşuyor. Bu gibi söylemek daha iyidir ki türkçe bir dünyadır ve biz yani insanlar türkçeyle yaşiyoruz ama sadece konuşma telefozları biraz zor ama bu normal bir şey çünkü dünyada da bazı kötü şeyler vardır.

Biraz beyaz biraz siyah yani bazı kolay bazı çok zor hesset ediyorum ama çok güzel bir dilli.

Elması nasıl ki herkes de olamaz ve hastır Türkçe dillide hastır her kes konuşamaz.

Çok lezzetli enerjik ve onu çok seviyorum. Sonunda bilmiyorum ama her renkler var.

Erkekler çok yakışıyor bu yüzden güçlü. Ve kibar çünkü sesli harfler çok.

Çok şeyler var. Ve farklı bir dil. Ama gerçekten çok güzeldir. Bu yüzden denize benzettim. Çünkü denize bakmak çok güzel. Ama girmek için çok şeyler yapmak lazım.

Herkes onun suyundan içmek istiyor. Tadına bakansa kimsey ondan uzaklaşmak istemez ve içtikçe suyundan doymaz. Yani Türkçe çok sevimli bir dil. Herkes onu öğrenmek ister ve biri öğrenmeye başladıysa ne kadar güzel farkeder ve her zaman daha fazla içinde yüzmek ister. 
Tablo 5'e bakıldığında 30 öğrencinin Türkçeye karşı olumlu his besledikleri açıkça görülmektedir. Öyle ki bazı öğrenciler bu hislerini çok çarpıcı metafor ve açıklamalarıyla ifade etmişlerdir. Örneğin Ö85 numaralı öğrenci, Türkçeyi pandaya benzetmiş ve gerekçesini şöyle açıklamıştır: "Biraz beyaz biraz siyah yani bazı kolay bazı çok zor hesset ediyorum ama çok güzel bir dilli." Buna ek olarak Ö93 numaralı öğrenci, Türkçeyi elmasa benzetmiş ve gerekçesini "Elması nasıl ki herkes de olamaz ve hastır Türkçe dillide hastır her kes konuşamaz." şeklinde ifade etmiştir.

Öğrencilerin Türkçeye yönelik olumlu hislerini genel olarak sevdikleri bir şeyle açıklamaya çalıştıkları görülmektedir. Bu nedenle Türkçeyi (arkadaş, baklava, salata, aile, yapboz, restoran, oyun, parfüm vb.) metaforlarıyla açıklamaya çalışmaları öğrencilerin Türkçeye karşı olumlu bir his beslediklerini kanıtlamakla birlikte Türkçeyi neden öğrendikleri hakkında fikir de vermektedir.

Tablo 6: Türkçeyi zor bulanların ürettikleri metaforlara ilişkin veriler

\begin{tabular}{|c|c|c|}
\hline No & Metafor & Metaforun Gerekçesi \\
\hline Ö14 & Kar & $\begin{array}{l}\text { Bence Türkçe dil, kültür çok farklı ve Türk dil çok zor çünkü başka bir dil gibi } \\
\text { değil bu yüzden Türk dili indi kar gibi. }\end{array}$ \\
\hline Ö19 & Deniz & $\begin{array}{l}\text { Türkçe çok derin bir dil çok gramerli. Türkçe zor bir dil yabancılar için bu } \\
\text { rejimde yaygın olarak söylenildiği için çok önemlidir. }\end{array}$ \\
\hline Ö32 & Film & $\begin{array}{l}\text { Ona görüyor kolaydır, ona dinliyor zor değildir, okuyor çok zor değildir ama } \\
\text { kullanmak için çok kolay değildir. Türkçe öğrenmek için vakit lazım, ona tekrar } \\
\text { lazım ve hatta her gün ona konuşmak iyidir. }\end{array}$ \\
\hline Ö33 & Kekeme & $\begin{array}{l}\text { Ben hala kötü konuşuyorum, belki çünkü pratik yapmadım. Bu nedenle kekeme } \\
\text { gibi ben konuşuyorum. }\end{array}$ \\
\hline Ö34 & Oyuncak tramvay & $\begin{array}{l}\text { Kalemler yapmak siz kalemi parçalar bu sebeple Türkçe'de bol bol kalemler çok } \\
\text { uzu. Bazen Türkçesiz insanlar söyle bu dil ses sihiirli kalemler gibi. Mesela: o } \\
\text { kork u yor um }\end{array}$ \\
\hline Ö53 & Uzun verimli bir ağaç & $\begin{array}{l}\text { Uzun ağaca tırmanması ağaç ürünü almak için çok çaba gerektirir. En başta } \\
\text { tırmanmayı öğrenmeye mecburum, ve ürünlere ulaşsam onları nasıl alacağım } \\
\text { çok pratik yapmam lazım, ve konsantrasyon çok önemli çünkü ağaçta dallar çok } \\
\text { benziyor ve yanlış bir şey yapabilirin, bu yüzden dikkatli olmalı. }\end{array}$ \\
\hline Ö65 & Ters koşan bir adam & $\begin{array}{l}\text { Başka dillerden farklı bir dil, bütün cümleler ters yazmalıyız ve okumalıyız o } \\
\text { yüzden bazen türkçe okurken ya da yazarken zor olabilir. }\end{array}$ \\
\hline Ö69 & Buzdolabı & $\begin{array}{l}\text { İçinde her şey var bazen tatlı ve bazen acıdır çünkü Türkçe içinde bazen } \\
\text { kelimeler ve grameler kolay ama bazen çok zor. }\end{array}$ \\
\hline Ö74 & Tuz & Türkçe nedeniyle tansiyonum artandır. \\
\hline Ö82 & Ödül & Bence bu dili çok zor, kim hangi örenecek sanki büyük bir ödül kazanacak... \\
\hline
\end{tabular}




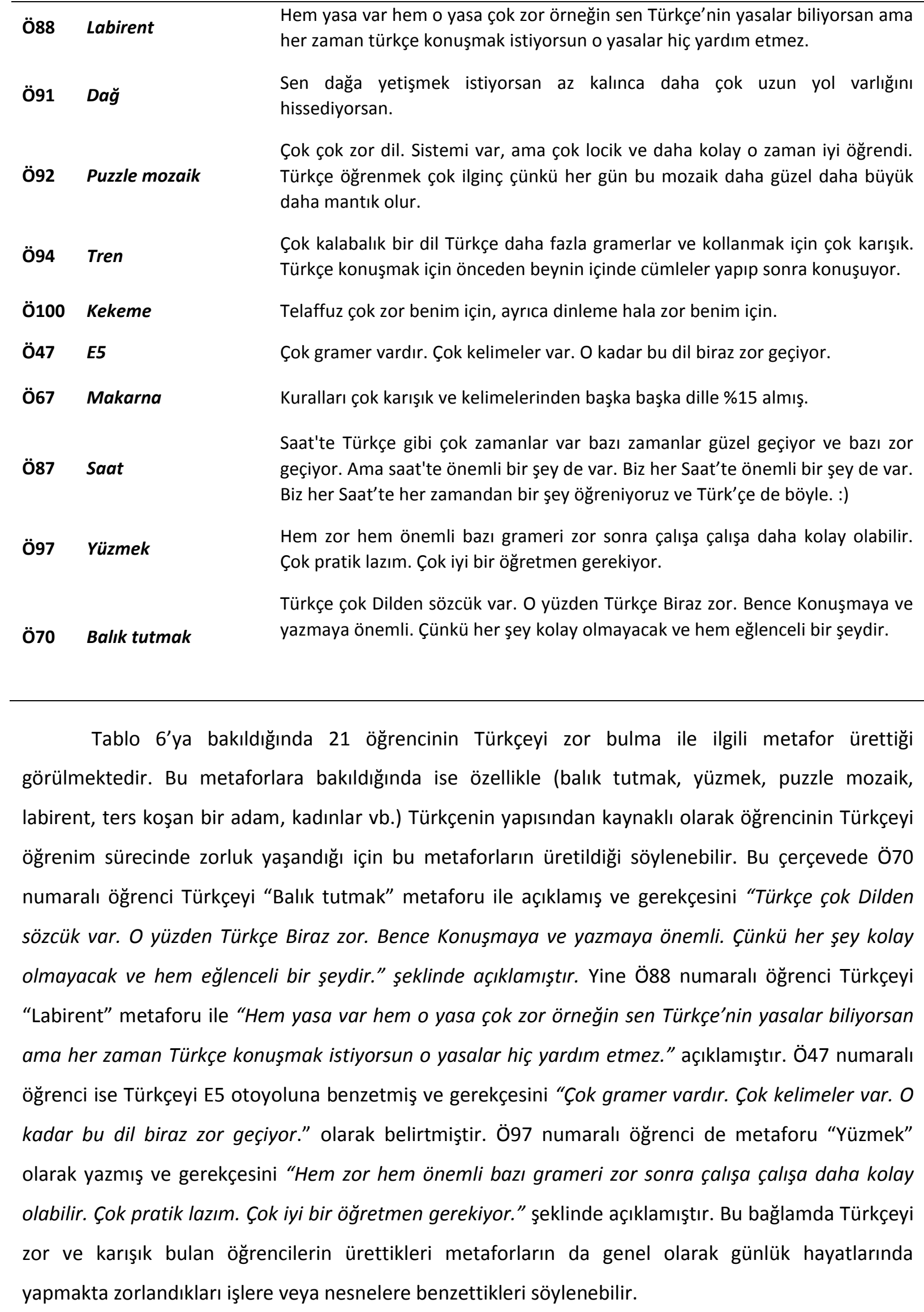


Türkçeyi Yabancı Dil Olarak Öğrenenlerin Türkçeye Yönelik Algılarının Metaforlar Aracılığı İle Belirlenmesi

Tablo 6: Diller arası ilişkiler teması altında üretilen metaforlara ilişkin veriler

\begin{tabular}{|c|c|c|}
\hline Öğrenci No & Metefor & Meteforun Gerekçesi \\
\hline Ö7 & Korece + Ingilizce + biraz Arapça & $\begin{array}{l}\text { Türkçenin yapısı Korece gibi özne obje fiil sırayladır. Ama } \\
\text { ingilizce gibi alfabe var ve kelimeler ingilizce'den gelir. Ayrıca } \\
\text { Arapça'dan kelimeler gelir. }\end{array}$ \\
\hline Ö20 & Farsça & Çok isimler ve harfler Turkçe gibi kullanıyor ve söyleyor. \\
\hline Ö21 & Farsça & Bazı kalımalar ve isimler Turkçe gibi. \\
\hline Ö22 & Arapça & $\begin{array}{l}\text { Çok kelimeler vardır benzemek ve yakın bir alışkanlıklar var ve } \\
\text { tellafuz benzer. }\end{array}$ \\
\hline Ö25 & Arapça aksine (Ters) & $\begin{array}{l}\text { Onun fiili her zaman en son be aktör, nesne ve olay her şey } \\
\text { fiilden önce ama arapça çok farklı. }\end{array}$ \\
\hline Ö59 & Karışık meyve suyu & $\begin{array}{l}\text { Bu dilin içinde sanki çok diller var, birçok kelimeler başka } \\
\text { dilinden gelmiş mesela Fransızca kelimeler Ingilizce, Arapça, } \\
\text { Fransızca hatta Çince'de vardır. }\end{array}$ \\
\hline Ö81 & Google & Çok Arapça ve ingilizce ve Fransız kelime var. \\
\hline ö95 & Telefon & $\begin{array}{l}\text { Onunda her şey ve her hangi farklı dil var. Ama orada sadece } \\
\text { bir sistem var o sistem talep ederse o sade bir dil. }\end{array}$ \\
\hline Ö58 & Bahçe & $\begin{array}{l}\text { Çok çiçekler var. Her çiçek farklı bir dil. Biraz benziyor ama } \\
\text { aynı zamanda çok fark var. }\end{array}$ \\
\hline
\end{tabular}

Tabloya bakıldığında 9 öğrencinin Türkçeyi genel olarak kendi ana dillerine benzettiği veya Türkçeyi bildiği bir dil ile ilişkilendirdiği görülmektedir. Bunun nedeni ise Türkçenin diğer dillerle olan ilişkisi ile açıklanabilir. Öyle ki Ö59 numaralı öğrenci Türkçeyi "karışık meyve suyu" metaforu ile açıklamış ve gerekçesini "Bu dilin içinde sanki çok diller var, birçok kelimeler başka dilinden gelmiş mesela Fransızca kelimeler Ingilizce, Arapça, Fransızca hatta Çince'de vardır." şeklinde açıklamıştır. Ö20 numaralı öğrenci ise Türkçeyi “Farsça” ya benzetmiş ve gerekçesini "Çok isimler ve harfler Türkçe gibi kullanıyor ve söylüyor" olarak belirtmiştir. Ö81 numaralı öğrenci de Türkçeyi "Google" metaforu ile "Çok Arapça ve ingilizce ve Fransız kelime var." açıklamıştır.

Yukarıdaki bilgilerden hareketle öğrencilerin Türkçeyi öğrenme süreçlerinde doğal olarak Türkçenin kendi ana dilleriyle veya bildikleri diğer yabancı dillerle benzerlik, ortaklık veya farklı yönlerini dikkate alarak öğrendikleri söylenebilir. Bu çerçevede tabloya bakıldığında öğrencilerin ürettikleri metaforların bu eksende olduğu göze çarpmaktadır. Bu da öğrencilerin Türkçeyi öğrenirken kendi ana dilleri veya bildiği dille muhakkak karşılaştırdıkları, bu durumun da onların Türkçe öğrenme başarıları doğrudan veya dolaylı olarak etkilediğini iddia edilebilir. 
Kur seviyelerine göre öğrencilerin ürettikleri metaforların temalara dağılımı nasıldır?

Araştırmaya katılan öğrencilerin Türkçeye ilişkin ürettikleri metaforların kur seviyelerine göre dağılımına ait veriler aşağıdaki gibidir:

Tablo 7: Seviyelere göre üretilen metaforların dağılımına ilişkin bulgular

\begin{tabular}{lllllll}
\hline & Olumlu His & intiyaç & Diller Arası ilişki & Zor bulma & Tasnif dışı & Toplam \\
\hline A2 & 15 & 12 & 5 & 5 & 5 & 42 \\
B1 & 7 & 18 & 2 & 11 & 3 & 41 \\
B2 & 8 & 1 & 2 & 5 & 1 & 17 \\
\hline
\end{tabular}

Yukarıdaki tabloya bakıldığında A2 öğrencilerinin ürettikleri metaforların 15'i Türkçeye karşı olumlu his, 12 'si ihtiyaç, 5'i zor bulma ve 5'i diller arası ilişki temasına dağıldığı görülmektedir. B1 öğrencilerinin ürettikleri metaforların ise 7'si olumlu his, 18 'i ihtiyaç, 11 'i zor bulma ve 2'si diller arası ilişki temasında yoğunlaşmıştır. Son olarak B2 öğrencilerinin ürettikleri metaforların da 8'i olumlu his, 1'i ihtiyaç, 5'i zor bulma ve 9'u diller arası ilişki temasındadır. Bu bilgilere ek olarak araştırmada A2 seviyesinde 5, B1 seviyesinde 3 ve B2 seviyesinde 1 öğrencinin ürettiği metaforun tasnif dışı edildiği görülmektedir. Bütün bu bilgilerden hareketle;

- A2'den B2'ye kadar tasnif dışı sayısı azalıyor. Seviye arttıkça öğrencinin kendini ifade edebilme becerisi artıyor. Bu da metafor üretme ve Türkçe bilme arasında doğrudan bir ilişkinin olduğunu, öğrencilerin Türkçe seviyelerinin arttıkça daha net veya doğru metafor ürettikleri söylenebilir.

- Türkçeyi zor bulma oranı orta seviyede (B1-B2) temel seviyeye (A2) göre daha fazladır. Öyle ki A2 seviyesinde 42 öğrencinin \%11,90'ı B1 seviyesindeki 41 öğrencinin \%26,82'si, B2 seviyesinde ise 17 öğrencinin \%29,41'i Türkçeyi zor bulmaktadır. Bunun sebebi ise özellikle B1 seviyesinin dil öğreniminde "eşik" olarak görülmesi ve A1 ile A2 seviyelerinin daha çok Türkçeyi yabancı dil olarak öğrenenler için dilin temel işlevlerini kavrama, günlük basit kalıplarla konuşma, dilin temel basit kurallarını öğrenme vb. süreçleri kapsamasıdır. Öyle ki ders kitapları göz önünde bulundurulduğunda özellikle gramerlerin B1 seviyesinde yoğunlaşmaya başladığı görülmektedir. Bu görüş doğrultusunda Fidan (2016) "Diller İçin Avrupa Ortak Başvuru Metni çerçevesinde A1 ve A2 düzeylerinin öğrenicinin, öğrenmeye başladığı dille ilk ilişkilerinin başladığı ve öğrenicinin birincil ihtiyaçlarını gidermek ve hayatını idame ettirmek için gerekli yapıların kazandııılığı bir çeşit 'geçiş evresi' olduğunu belirterek bu düzeylerde öğreniciye dilbilgisi yüklemesi yapmak yerine, yaptırılan dilbilgisi çalışmalarının daha çok o dil sisteminin nasıl işlediğinin mantığının yerleştirilmesi biçiminde olması; dilbilgisine yoğunlaşmanın B1 ile başlanmasının, eğitimden beklenen kazanımların kalıcılığını artıracağını vurgular. Bu bağlamdan hareketle Fidan (2016)'nın bu görüşü araştırmanın sonucu ile birebir örtüşmektedir. 
Türkçeyi Yabancı Dil Olarak Öğrenenlerin Türkçeye Yönelik Algılarının Metaforlar Aracılığı İle Belirlenmesi

- B2'deki öğrenciler Türkçeyi intiyaç olarak görmüyor. Bu durum öğrencilerin Türkçeyi öğrendikleri için onlar için artık bir ihtiyaç olmaktan çıktığının kanıtıdır. Öyle ki ihtiyaç duyulan bir şeye sahip olunduktan sonra o şeyin ihtiyaç olma durumunu yitirmesi doğal bir durumdur. Ayrıca Aydın TÖMER'de Türkçe öğrenen öğrenciler B1 seviyesini tamamladıktan sonra üniversitenin lisans bölümlerine kayıt yapabildikleri için B2 seviyesinde sadece 1 kişinin Türkçeyi intiyaç olarak görmesinin nedeni bu durum da olabilir. Bu çerçevede B2 kurslarına gelen öğrencilerin intiyaç duydukları için değil istedikleri için Türkçe öğrendikleri yorumunda bulunulabilir.

- A2 seviyesindeki öğrencilerde olumlu his teması diğer seviyelere göre daha yüksek görünüyor. Bu durum özellikle dil öğreniminde motivasyon unsuru ile açıklanabilir. Bu nedenle genel olarak dil öğreniminde öğrencinin öğrenmeye başladığı dile karşı tutumu ve algısı temel seviyelerde daha yoğun olabilmektedir. Bu nedenle A2 seviyesindeki öğrencilerin Türkçeye karşı olumlu tutumları bu bağlamda açıklanabilir.

Cinsiyetlere göre öğrencilerin ürettikleri metaforların temalara dağılımı nasıldır?

Aşağıdaki tabloda araştırmaya katılan öğrencilerin ürettikleri metaforların cinsiyetlerine göre dağılımına ilişkin bulgular bulunmaktadır.

Tablo 8: Cinsiyete göre metaforların temalara göre dağılımına ilişkin veriler

\begin{tabular}{lllllll}
\hline & Olumlu His & ihtiyaç & Diller Arası Ilişki & Zor bulma & Tema dışı & Toplam \\
\hline Erkek & 17 & 20 & 4 & 8 & 2 & 51 \\
Kadın & 13 & 11 & 5 & 13 & 7 & 49 \\
Toplam & 30 & 31 & 9 & 21 & 9 & 100 \\
\hline
\end{tabular}

Tablo 8'e bakııdığında erkek ve bayanların Türkçeye ilişkin ürettikleri metaforların temalara göre dağılımı arasındaki en belirgin fark intiyaç temasında görünmektedir. Bu çerçevede Erkeklerin 20'si Türkçeyi ihtiyaç olarak görürken bayanların 11'i ihtiyaç olarak görmektedir. Bu bağlamda erkeklerin iş, okul vb. gerekçelerle Türkçeye kadınlardan daha fazla ihtiyaç duyduğu söylenebilir. Tabloda dikkat çeken diğer bir husus ise bayan öğrencilerin erkek öğrencilere göre Türkçeyi daha fazla zor bulduğu görülüyor.

Uyruğa göre öğrencilerin ürettikleri metaforların temalara dağılımı nasıldır?

Aşağıdaki tabloda araştırmaya katılan öğrencilerin ürettikleri metaforların uyruklarına göre dağııımına ilişkin bulgular bulunmaktadır.

Tablo 9: Ülkelere göre metaforların temalara göre dağılımına ilişkin veriler

\begin{tabular}{lllllll}
\hline & Olumlu His & intiyaç & Diller Arası iliş̧i & Zor Bulma & Tema Dışı & Toplam \\
\hline Afganistan & 8 & 12 & 3 & 2 & 1 & 26 \\
\hline
\end{tabular}




\begin{tabular}{|c|c|c|c|c|c|c|}
\hline Çin & 4 & 1 & - & 1 & 1 & 7 \\
\hline Fas & - & - & - & 2 & - & 2 \\
\hline Filistin & 2 & 3 & 1 & 1 & 1 & 8 \\
\hline G. Kore & - & 1 & 1 & - & - & 2 \\
\hline Irak & 2 & 2 & - & 1 & - & 5 \\
\hline İran & 3 & 2 & - & 2 & 1 & 8 \\
\hline Pakistan & - & - & - & 1 & - & 1 \\
\hline Rusya & - & - & - & - & 1 & 1 \\
\hline Somali & 1 & - & - & 1 & - & 2 \\
\hline Mısır & - & 3 & - & 2 & 1 & 6 \\
\hline Suriye & 6 & 5 & 2 & 3 & 3 & 19 \\
\hline S. Arabistan & - & 1 & - & - & - & 1 \\
\hline Tunus & 2 & - & 1 & 1 & - & 4 \\
\hline Ukrayna & 1 & - & - & 2 & - & 3 \\
\hline Ürdün & 1 & - & 1 & - & - & 2 \\
\hline Yemen & - & 1 & - & 2 & - & 3 \\
\hline Toplam & 30 & 31 & 9 & 21 & 9 & 100 \\
\hline
\end{tabular}

Yukarıdaki tabloya bakıldığında araştırmaya katılan öğrencilerin yoğun olarak Afganistan (26) ve Suriyeli (19) olduğu görülmektedir. Bu bağlamda ülkelere göre dağılımda öğrenci sayılarının çok olması sebebiyle en çok Afganistan ve Suriyeli öğrencilerin temalarında yorum yapmak mümkündür. Bu çerçevede;

- Araştırmaya katılan 26 Afgan öğrencinin sadece 2'si Türkçeyi zor bulduğunu belirtmiştir. Bu bağlamda Afganistanlı öğrencilerin Türkçeyi öğrenirken çok fazla zorluk yaşamadıkları yorumunda bulunulabilir.

- Afganistan uyruklu öğrencilerin büyük bir bölümü Türkçeyi intiyaç olarak görmektedir. Bunun sebebi ise Afganistan'ın içinde bulunduğu siyasi ve ekonomik kriz nedeni ile gençlerin Türkiye'ye gelmek ve eğitim hayatlarına burada devam etmek istemeleridir.

- Suriyeli öğrencilerde belirgin bir farklılık olmamakla birlikte olumlu his temasıyla birlikte ihtiyaç temasının öne çıktığı görülür.

- Araştırmaya katılan 8 Çinli öğrencinin 4'ü Türkçeye yönelik olumlu his beslediği görülmektedir. Bu çerçevede Çinli öğrencilerin Türkçeyi meraktan veya sevdikleri için öğrendikleri yorumu yapılabilir. 
Türkçeyi Yabancı Dil Olarak Öğrenenlerin Türkçeye Yönelik Algılarının Metaforlar Aracılığı İle Belirlenmesi

- Araştırmaya katılan 6 Mısırlı öğrencinin 2'si Türkçeyi zor bulduğunu, 2'si ise îhtiyaç olarak gördüğünü belirtmektedir.

- Göze çarpan bir diğer önemli nokta ise olumlu his besleyen öğrencilerin sayısıdır. Bu sayının fazla olması öğrencilerin Türkçeyi sevdiğine ya da severek öğrendiğine işaret olarak kabul edilebilir.

Arap öğrencilerin ürettikleri metaforların temalara göre dağılımı nasıldır?

Aşağıda, araştırmaya katılan Arap öğrencilerin Türkçeye ilişkin ürettikleri metaforların temalara göre dağılımına ilişkin veriler bulunmaktadır. Arap öğrencilerini ayrı bir başıkta incelememizin sebebi ise Arap ülkelerinden gelen öğrencilerin her ne kadar ülkeleri farklı olsa da aynı kültür ve aynı dile sahip olmalarının yanında araştırmaya katılan öğrencilerin yaklaşık \%50'sini oluşturmalarıdır.

Tablo 10: Arap öğrencilerin ürettikleri metaforların temalara göre dağıımı

\begin{tabular}{lcccccc}
\hline & Olumlu His & intiyaç & Diller Arası ilişki & Zor Bulma & Tema Dışı & Toplam \\
\hline Arap Öğrenciler & 13 & 15 & 5 & 12 & 5 & 50
\end{tabular}

Yukarıdaki tabloya bakıldığında araştırmaya katılan Arap uyruklu 50 öğrencinin 13'ünün Türkçeye karşı olumlu his beslediği, 15'inin Türkçeyi ihtiyaç olarak gördüğü, 5'inin Türkçe ile Arapça arasında bir ilişki kurduğu ve 12'sinin ise Türkçeyi zor bulduğu görülmektedir. Bu çerçevede genel olarak Arap uyruklu öğrencilere bakıldığı zaman büyük bölümünün Türkçeyi ihtiyaç olarak gördüğü söylenebilir. Bunun sebebi mülteci olarak Türkiye'de bulunan Arap nüfusun çoğunluğu ve Yemen, Suriye, Filistin gibi savaşın devam ettiği bölge insanlarının çoğunlukta olması gösterilebilir.

\section{Sonuç ve Öneriler}

Genelde dil öğretim sürecinde özelde ise yabancılara Türkçe öğretim sürecinde öğrencilerin öğreneceği dile karşı algısını bilmek şüphesiz dil öğretim başarısını doğrudan etkileyecektir. Öyle ki Lüle Mert (2013: 369 ) metaforların eğitim alanında da anlaşılmayan, anlaşılması zor olan konularda veya bazı kavram, algı ve tutumları daha anlaşıır ifade etmede kullanılabilir olduğunu vurgulamaktadır ve son yıllarda metaforların algıları belirlemede güçlü bir araştırma aracı olduğunu ortaya koyan birçok araştırmanın (Inbar 1996; Guerrero ve Villamil 2002; Saban ve Koçbeker 2006) var olduğunu belirtmektedir.

Bunlara ek olarak metaforların kavramların anlaşııması ve yorumlanmasını kolaylaştıran, kavramların nasıl algılandığını da ortaya çıkaran ve yeterince anlaşılmamış konuların daha rahatlıkla 
anlaşılmasını sağlamaya yardımcı nitelikte olduğu (Cerit, 2008; Rızvanoğlu, 2007; Şengül, Katrancı ve Gerez Cantimer 2014; Semerci, 2007) birçok araştırmacı tarafından vurgulanmıştır. Bu doğrultuda, yapılan bu çalışmada öğrencilerin Türkçe ile ilgili ürettikleri metaforlar göz önünde bulundurulduğunda öğrencilerin 31'inin Türkçeyi ihtiyaç olarak gördüğü, 21'inin Türkçeyi zor bulduğunu, 9'unun Türkçe ile ana dili ile veya bildiği bir dille ilişkilendirdiği, 30'unun ise Türkçeye karşı olumlu bir his beslediği görülmektedir. Bu çerçevede genel olarak Türkçeye yönelik algılarının olumlu yönde olduğu yorumu yapılabilir. Bu kapsamda öğrencilerin Türkçeye yönelik geliştirdikleri metaforlar ve gerekçeleri incelendiğinde;

- Öğrencilerin geliştirdikleri metaforların da Türkçe olduğu,

- Kendi ana dilleri ve kültürlerin etkisi altında kalmadan Türkçeyi Türkçe bir metaforla açıklayabildikleri,

- Türkçeyi bilinçli bir şekilde öğrendikleri,

- Düşünce dünyalarının dar olmadığı,

- Türkçeyi sadece kalıp olarak konuşmadıkları aynı zamanda Türkçe düşünebildikleri,

- Türkçenin özelliklerini ve dil yapısını bildikleri ve kendi ana dilleriyle kıyaslama yaptıkları söylenebilir.

Yukarıda sayılan bu maddelere kanıt olarak, Ö94 numaralı öğrencinin metafor olarak Türkçeyi "Tren" metaforu ile "Çok kalabalık bir dil Türkçe daha fazla gramerlar ve kollanmak için çok karışık. Türkçe konuşmak için önceden beynin içinde cümleler yapıp sonra konuşuyor." şeklinde açıklaması, Ö19 numaralı öğrencinin Türkçeyi "Deniz" metaforu ile "Türkçe çok derin bir dil çok gramerli. Türkçe zor bir dil yabancılar için bu rejimde yaygın olarak söylenildiği için çok önemlidir." Ö59 numaralı öğrencinin Türkçeyi "Karışık meyve suyu" metaforuyla "Bu dilin içinde sanki çok diller var, birçok kelimeler başka dilinden gelmiş mesela Fransızca kelimeler Ingilizce, Arapça, Fransızca hatta Çince'de vardır. “ Ö85 numaralı öğrencinin "Biraz beyaz biraz siyah yani bazı kolay bazı çok zor hesset ediyorum ama çok güzel bir dilli" biçiminde açıklamaları gösterilebilir. Bunlara ek olarak Göçer (2013) herhangi bir konuda metafor oluşturmasında en etkili unsurun bireyin kültürel birikimi olduğunu ve son zamanlarda, herhangi bir konuda kişilerin sahip olduğu algıların belirlenmesinde metafor oluşturma tekniği sıkıkla kullanıldığını belirtir. Bu çerçevede yabancı öğrencilerin Türkçeye yönelik kültürel ve Türkçe bilgi birikimlerinin iyi düzeyde olduğu söylenebilir.

Yukarıdaki bilgilerden hareketle özellikle yabancılara Türkçe öğretiminde öğrencilerin Türkçeye yönelik algılarının belirlenmesinde "metafor" kullanımı önem arz etmektedir. Eğitimde sürekli başvurulan bir araç olan metaforun Türkçe öğretiminde de kullanılması Türkçenin yabancılara 
öğretiminde öğrenciyi tanıma, süreci yönlendirme, öğretim planını ayarlama, ders kitaplarının yazımı, öğretmen yetiştirme vb. birçok alanda iyileştirme yapılmasına doğrudan katkı sağlayacaktır. Bu çerçevede;

- Türkçenin yabancı dil olarak öğretimi literatürüne metafor kavramı eklenmeli ve alanla ilgili yapılacak tez, makale vb. araştırmaların sayısı artırılmalıdır.

- Yabancılara Türkçe öğretenlerin eğitimi sürecinde, dil öğretiminde metafor kullanımının ne işe yarayacağına yönelik bilgi verilmelidir.

- Hangi seviyede olursa olsun öğretmenler öğrencilerin Türkçeye yönelik algılarını süreç başında metaforlar aracılığı ile belirlemeli ve ders süreçlerini bu doğrultuda planlamalıdır.

- Metaforun sadece algıyı belirleme veya ölçmede değil diğer alanlarda da (kelime, deyim, atasözü öğretimi vb.) nasıl kullanılabileceğine dair araştırmalar yapıımalıdır.

- Dil öğretim sürecinde özellikle öğrencilerin dinleme, okuma, konuşma, yazma ve dil bilgisine yönelik algılarını ölçmede mutlaka metafordan yararlanılmalıdır. Örneğin, "yazma dersleri benim için oyun gibidir" yazan bir öğrenci ile "ter koşan bir adam gibidir" yazan öğrencinin yazma dersine yönelik tutumu, kaygısı ve algısı hakkında doğrudan bilgi sahibi olunacağı için bu yönteme mutlaka başvurulmalıdır.

\section{Kaynaklar}

Akkaya, A. (2013). Suriyeli Mültecilerin Türkçe Algıları. Ekev Akademi Dergisi Yıl: 17 Sayı: 56, 179-190.

Altun, S. A., ve Apaydın, Ç. (2013). Kız ve Erkek Öğretmen Adaylarının "Eğitim" Kavramına Iliş̧in Metaforik Algıları. Kuram ve Uygulamada Eğitim Yönetimi Dergisi, 19(3), 329-354.

Arslan, M., ve Bayrakçı, M. (2006). Metaforik düşünme ve öğrenme yaklaşımının eğitim- öğretim açısından incelenmesi. Millî Eğitim Dergisi, 171, 100-108.

Aydın, S. ve Pehlivan, A. (2010). Türkçe Öğretmeni Adaylarının "Öğretmen” ve "Öğrenci" Kavramlarına ilişskin Kullandıkları Metaforlar. Turkish Studies, 5/3, 817- 842.

Cerit, Y. (2008). Öğretmen Kavramı Ille Illgili Metaforlara ilişkin Öğrenci, Öğretmen ve Yöneticilerin Görüşleri. Türk Eğitim Bilimleri Dergisi, 6(4), 693-712.

Çalışkan, N. (2009). "Kavramsal Anahtar Modeliyle iki Dilli Çocuklara Metafor ve Deyim Öğretimi" Yayımlanmamış Doktora Tezi, Gazi Üniversitesi, Sosyal Bilimler Enstitüsü, Ankara.

Çalışkan, N. (2010). Türkçenin Yabancı Dil Olarak Öğretiminde Söz Varlığını Geliştirme: Kavramsal Anahtarlar Aracılığıyla Deyim Öğretimi. Turkish Studies International Periodical For the Languages, Literature and History of Turkish or Turkic Volume 5/4.

Çalışkan, N. (2013). Kavramsal Anahtar Modeli ile Metafor ve Deyim Öğretimi. Bilig, (64), 95-122.

Demirci, K. (2016). "Metafor: Bir Anlatım ve Üretim Mekanizması" Dil Bilimleri Kültür ve Edebiyat, (Edt. M Sarıca, B. Sarıca), Padam Yayınları, Ankara, s.330-343) 
Dumanlı Kadızade, E. (2014). Aktif Öğrenmede Bir Teknik; Metafor Uygulaması "Türkçe Öğretmen Adaylarının Türkçe Dersi Algıları Üzerine" International Journal of Language Academy. Volume 2/4 Winter 2014 p. 68-85.

Fidan, D. (2016). Türkçenin Yabancı Dil Olarak Öğretimi Ders Kitaplarındaki Dilbilgisi Konuları ve ÖğretmenÖğrenici Görüşleri / Grammar Subjects in Turkish as a Foreign Language Course Books and Teachers' Learners' Views", Turkish Studies, 11/14 Summer, 257-2"76.

Fidan, M. (2014). “Öğretmen Adaylarının Teknoloji Ve Sosyal Ağ Kavramlarına Iliş̧kin Metaforik Algıları.” The Journal of Academic Social Science Studies, Number: 25-I, p. 483-496,

Göçer, A. (2013). Türkçe Öğretmeni Adaylarının ‘Kültür Dil ilişskisi’ne Yönelik Metaforik Algıları. Turkish Studies - International Periodical For The Languages, Literature and History of Turkish or Turkic Volume 8/9 Summer 2013, p. 253-263

Guerrero, M. ve Vıllamı, O. (2002). Metaphorical Conceptualizations of ELS Teaching and Learning Language Teaching Researh, 6, 2, 95-120.

Kalyoncu, R. (2012). "Görsel Sanatlar Öğretmeni Adaylarının “Öğretmenlik” Kavramına ilişkin Metaforları.” Mustafa Kemal Üniversitesi Sosyal Bilimler Enstitüsü Dergisi. Cilt 9 Sayı 20, s. 471-484.

Lüle Mert, E. (2013). Türkçe Öğretmen Adaylarının Dört Temel Dil Becerisine iliş̧kin Algılarının Metaforlar Aracılığıyla Analizi. Uluslararası Sosyal Araştırmalar Dergisi,6 (27). 357-372.

Pilav, S. ve Elkatmış, M. (2013). “Öğretmen adaylarının Türkçe kavramın ilişkin metaforları” Turkish Studies International Periodical For The Languages, Literature and History of Turkish or Turkic; Volume 8/4 p. 1207-1220, Ankara

Rızvanoğlu, K. (2007). Grafik Kullanıcı Ara yüzlerinde Metaforların Kültürlerarası Kavranışı (Fransa ve Türkiye'de Bir e-Öğrenme Sitesi Üzerinden Karşılaştırmalı Bir Çalışma). Doktora tezi, Marmara Üniversitesi Sosyal Bilimler Enstitüsü, İstanbul.

Saban, A. (2008). İlköğretim I. kademe öğretmen ve öğrencilerinin bilgi kavramına ilişkin sahip oldukları zihinsel imgeler. ilköğretim Online, 7 (2), 421-455.

Saban, A., Koçbeker, B. N., ve Saban, A. (2006). Öğretmen adaylarının öğretmen kavramına ilişkin algılarının metafor analizi yoluyla incelenmesi. Kuram ve Uygulamada Eğitim Bilimleri, 6(2), 461-522.

Semerci, Ç. (2007) "Program Geliştirme Kavramına İlişkin Metaforlarla Yeni İlköğretim Programlarına Farklı Bir Bakış” C.Ü. Sosyal Bilimler Dergisi, 31, 125-140.

Şengül, S. Katrancı, Y. ve Gerez Cantimer, G. (2014). Ortaöğretim Öğrencilerinin "Matematik Öğretmeni" Kavramına İlişkin Metafor Algıları. The Journal of Academic Social Science Studies, s. 25. Ss. 89-111.

Şeyhoğlu, A., ve Gençer, G. (2011). Hayat Bilgisi Öğretiminde “Metafor” Tekniğinin Kullanımı. TüRK FEN Eğitimi Dergisi, 8 (3).

Vadebocoeur, Jennifer A. Myriam N. T. (2003). “Constructing and Reconstructing Teaching Roles: A Focus On Generative Metaphors and Dichotomies", Discourse: Studies in the Cultural Politics of Education, Carfax Publishing, Vol: 24, No:1

Yıldım A. ve Şimşek H. (2011). Sosyal Bilimlerde Nitel Araştırma Yöntemleri. Ankara: Seçkin Yayınevi.

http://www.tdk.gov.tr/index.php?option=com gts\&arama=gts\&guid=TDK.GTS.58dd137b146e38.88791049 (erişim tarihi:15.03.2017) 